\title{
UROLOGIC MANIFESTATIONS OF GOLDENHAR SYNDROME
}

\author{
MICHAEL L. RITCHEY, M.D. \\ JOHN NORBECK, M.D. \\ CINDY HUANG \\ MICHAEL A. KEATING, M.D. \\ DAVID A. BLOOM, M.D.
}

\begin{abstract}
From the Department of Surgery, Section of Urology, University of Michigan, Ann Arbor, Michigan, and the Division of Pediatric Urology, The James Whitcomb Riley Hospital for Children, Indiana University, Indianapolis, Indiana
\end{abstract}

\begin{abstract}
Objective. Goldenhar syndrome (oculoauriculovertebral dysplasia) is associated with anomalies in multiple organ systems. Renal abnormalities have also been reported with the complex, but the incidence of associated genitourinary malformations has not been defined.

Method. We have reviewed our experience with 28 children with Goldenhar syndrome evaluated during the past twelve years. Twenty children underwent imaging evaluation of the urinary tract and 14 (70\% of those imaged) children had urinary tract anomalies.

Results. The majority of anomalies presented as an incidental finding on a screening ultrasound ( 8 patients) or during cardiac catheterization ( 2 patients). Two children presented with urinary tract infection, 1 child presented with renal failure, and another was diagnosed antenatally. The genitourinary anomalies included the following: ectopic and/or fused kidneys (8 patients), renal agenesis (7), vesicoureteral reflux (5), ureteropelvic junction obstruction (2), ureteral duplication (2), and multicystic kidney (1 patient). Four children have undergone surgical intervention.

Conclusion. Our experience in children with Goldenhar syndrome suggests that the incidence of genitourinary anomalies is higher than previously reported. A screening ultrasound in the neonatal period allows for early intervention in those children with significant urologic abnormalities.
\end{abstract}

Goldenhar syndrome (also referred to as oculoauriculovertebral dysplasia, first and second branchial arch syndrome) is a complex of unilateral craniofacial and vertebral anomalies. ${ }^{1,2}$ Signs associated with the syndrome include preauricular skin tags, epibulbar dermoids, cleft palate, maxillary or mandibular hypoplasia, ear microtia, and facial asymmetry. Patients may show some or all of these signs to various degrees. Anomalies of other organ systems have been noted frequently particularly cardiac, neural, and pulmonary. ${ }^{3}$ Renal abnormalities have also been reported with the complex, ${ }^{4-7}$ but the incidence of associated genitourinary (GU) malformations has not been

Submitted: July 30, 1993, accepted (with revisions): September 3, 1993 defined. Recent experience with a number of children found to have associated upper urinary tract abnormalities prompted us to review a large group of children with Goldenhar syndrome evaluated at our institutions during the past twelve years to determine the incidence of $\mathrm{GU}$ anomalies in affected children.

\section{MATERIAL AND METHODS}

Twenty-four children with Goldenhar syndrome have been evaluated at the University of Michigan since 1980. Two of 4 children with Goldenhar syndrome treated at the Indiana University and found to have urologic abnormalities are also included in this report. The age at diagnosis of the urologic anomaly ranged from one day to six years, with a median age of two years. There were 


\begin{tabular}{|c|c|c|c|c|c|}
\hline Patient & $\begin{array}{l}\text { Age at Diagnosis } \\
\text { GU Anomaly }\end{array}$ & $\begin{array}{c}\text { Clinical } \\
\text { Presentation }\end{array}$ & VCUG & Urologic Anomaly & Surgical Intervention \\
\hline MK & 6 yrs & $\begin{array}{l}\text { Urinary tract } \\
\text { infection }\end{array}$ & No VUR & $\begin{array}{l}\text { Crossed fused ectopia, } \\
\text { partial R UPJ obstruction }\end{array}$ & \\
\hline KK & 3 yrs & Screening UTZ & R VUR & Fused pelvic kidney & Vesicostomy \\
\hline $\mathrm{KP}$ & 2 yrs & $\begin{array}{l}\text { Urinary tract } \\
\text { infection }\end{array}$ & No VUR & $\begin{array}{l}\text { Lduplication with ectopic } \\
\text { ureter (upper), UPJ (lower) }\end{array}$ & $\begin{array}{l}\text { Pyeloplasty, } \\
\text { ureteropyelostomy }\end{array}$ \\
\hline $\mathrm{HB}$ & $4 y r s$ & Screening UTZ & Not done & $\begin{array}{l}\text { R pelvic kidney, } \\
\text { agenesis L kidney }\end{array}$ & \\
\hline JC & 2 yrs & Screening UTZ & LVUR & $\begin{array}{l}\text { Lpelvic kidney } \\
\text { agenesis R kidney }\end{array}$ & Ureteral reimplant \\
\hline $\mathrm{HC}$ & 3 mos & Screening UTZ & LVUR & Agenesis R kidney & $\ldots$ \\
\hline$J L$ & $3 y r s$ & Cardiac cath & Not done & $\begin{array}{l}\text { L pelvic kidney, } \\
\text { bilateral UDT }\end{array}$ & Bilateral orchidopexy \\
\hline $\mathrm{MN}$ & $2 \operatorname{mos}$ & Cardiac cath & Not done & R pelvic kidney & . \\
\hline IF & $1 w k$ & Screening UTZ & No VUR & Agenesis L kidney & . \\
\hline$C D$ & $1 \mathrm{mo}$ & Screening UTZ & Not done & Agenesis L kidney & $\cdots$ \\
\hline AS & 6 days & Renal failure & No VUR & $\begin{array}{l}\text { Agenesis L kidney, } \\
\text { ectopic R ureter to vagina }\end{array}$ & \\
\hline $\mathrm{BC}$ & $1 \mathrm{mo}$ & Screening UTZ & Not done & $\begin{array}{l}\text { L duplication, hydronephrosis } \\
\text { of upper pole }\end{array}$ & . \\
\hline MN & $1 w k$ & Screening UTZ & LVUR & R multicystic dysplastic kidney & R nephrectomy \\
\hline ZM & Antenatal & Antenatal UTZ & R VUR & Agenesis L kidney & $\ldots$ \\
\hline
\end{tabular}

5 males and 9 females. The majority of patients with abnormalities of the urinary tract presented as an incidental finding on a screening abdominal ultrasound (8) or during cardiac catheterization (2). Two children presented with urinary tract infection, 1 child presented with renal failure, and another was diagnosed antenatally.

\section{RESULTS}

Twenty of the 28 children with Goldenhar syndrome included in this series underwent imaging evaluation of the urinary tract and $14(70 \%$ of those imaged) children had urinary tract anomalies. Six children evaluated with either renal ultrasound (5) or intravenous urogram (1) had normal kidneys. These were all performed for screening purposes and none of these 6 children have had any urologic problems. Eight children had no imaging of the urinary tract. One of these patients has been evaluated for nocturnal enuresis, and another boy underwent bilateral orchidopexy at age three years for cryptorchidism. The remainder of the patients are asymptomatic from a genitourinary standpoint.

All of the patients with genitourinary abnormalities are listed in Table I. The GU anomalies included: ectopic and/or fused kidneys (8), renal agenesis (7), vesicoureteral reflux (VUR) (5), ureteropelvic junction obstruction (2), ureteral duplication (2), and multicystic dysplastic kidney (1). Four children have undergone surgical intervention; 2 for relief of obstruction, removal of a dysplastic kidney in 1 child and ureteral reimplantation to correct high-grade vesicoureteral reflux in another patient with recurrent urinary tract infection.

With the exception of 2 children, all have maintained normal renal function. In 1 child with sacral agenesis hydronephrosis developed secondary to her neurogenic vesical dysfunction. She was initially managed with intermittent catheterization and anticholinergics, but has subsequently undergone cutaneous vesicostomy. Although her renal function has stabilized, she continues to have renal insufficiency (corrected creatinine clearance of $30 \mathrm{~mL} / \mathrm{min}$ ). Another child presented with renal failure and was found to have an absent left kidney, a single system right ureter ectopic to the vagina, and urethral atresia with an extremely small bladder. This patient also had significant cardiac malformations and died secondary to renal failure.

Anomalies of other organ systems were frequently noted. Nine children had cardiac malformations, 4 had pulmonary abnormalities, and 3 children had skeletal anomalies. One child had a 
tracheo-esophageal fistula, 1 girl had partial vaginal atresia, and 1 child had spinal dysraphism.

\section{COMMENT}

Several case reports document renal malformations in patients with Goldenhar syndrome. ${ }^{4-7}$ None of the reports, however, have defined the incidence of genitourinary abnormalities in a group of children with this syndrome. In Smith's Recognizable Patterns of Human Malformations, ${ }^{8} \mathrm{GU}$ abnormalities are not listed as a major feature of this syndrome, therefore the 50 percent incidence (70\% of patients imaged) of renal anomalies detected in our patients seems significant.

The etiology of Goldenhar syndrome is unclear. A number of chromosomal abnormalities have been reported. ${ }^{3-5}$ However, most children generally have normal chromosomes. This leads to the suggestion that the syndrome is not inherited but is a developmental defect occurring during the formation of the brachial arches and vertebral bodies. Teratogenic agents have also been implicated. ${ }^{3}$ Kennedy and Persaud ${ }^{9}$ postulated that extrauterine compression from oligohydramnios could result in the facial deformities. Others have suggested an abnormal vascular supply to the cephalic neural crest cells. ${ }^{2}$ None of the theories, however, fully explains the various patterns of widespread malformations seen in Goldenhar syndrome.

Cervical vertebral anomalies occur in 50-65 percent of cases. ${ }^{3}$ Anomalies of other vertebral bodies and/or spinal dysraphism occur in 30 percent of patients. It has been suggested that malformations of other organ systems are more likely to occur in children with cervical spine abnormalities. ${ }^{10}$ Nine of our 12 patients had spinal abnormalities although only 1 patient had spinal dysraphism. The latter is particularly important to recognize early in life because of its deleterious effects on vesicourethral and renal function. A high index of suspicion, early diagnosis, and urodynamic evaluation would have prevented the problems encountered in our patient.

The association of renal anomalies with ear malformations is well known. Potter ${ }^{11}$ noted the association of renal agenesis with "large low-set ears which have disproportionately little cartilage." Hilson in $1957^{12}$ reported that $15 / 19$ cases referred for pyelography because of malformed ears had upper urinary tract anomalies. A number of related conditions which are also associated with renal anomalies bear resemblance to oculoauriculovertebral dysplasia. Brachio-oto-renal syndrome is associated with ear malformations and renal dysplasia. Inheritance is autosomal dominant, but hemifacial microsomia is not a component of this syndrome. ${ }^{13}$ Townes-Brock syndrome consists of dysplastic ears, anal defects, and renal anomalies. ${ }^{14}$ More recently, Leung and Robson ${ }^{15}$ found a 4.3 percent incidence of renal anomalies in children with preauricular sinuses and recommended routine screening renal ultrasound in such patients.

The preponderance of data suggests that children with ear malformations with or without associated recognizable syndromes are at increased risk for renal anomalies. All patients with oculoauriculovertebral syndrome should undergo screening ultrasound early in life. This should include examination of the kidneys, bladder, and the spine. Children discovered to have renal agenesis, multicystic dysplastic kidney, ectopic kidneys, or hydronephrosis should also undergo cystourethrography. These patients have been shown to have an increased incidence of VUR, ${ }^{16}$ and all patients in this report with VUR had an associated renal anomaly. Detection of renal anomalies in infancy allows earlier intervention for obstructive hydronephrosis and vesicoureteral reflux. In addition, children with unilateral renal agenesis or solitary functioning kidneys benefit from early detection; these patients may be at increased risk from renal damage secondary to hyperfiltration. ${ }^{17}$ Families should be counseled early in the lives of these children and close follow-up should be arranged.

Michael Ritchey, M.D.
Division of Pediatric Surgery
6431 Fannin, Suite 6.264
Houston, Texas 77030

\section{REFERENCES}

1. Goldenhar M: Associations malformatives de l'oeil et de l'oreille, in particular le syndrome dermoide epibulbaireappendices auriculares-fistula auris congenita et ses relations avec la dysostose mandibulofaciale. J Genet Hum 1: 243-282, 1952.

2. Gorlin RJ, Jue KL, Jacobsen U, and Goldschmidt E: Oculoauriculovertebral dysplasia. J Pediatr 63: 991-999, 1963.

3. Cohen MM Jr, Rollnick BR, and Kaye CI: Oculoauriculovertebral spectrum: an updated critique. Cleft Palate J 26: 276-286, 1989.

4. Wilson GN, and Barr M Jr: Trisomy 9 mosaicism: another etiology for the manifestations of Goldenhar syndrome. J Craniofac Genet Dev Biol 3: 313-316, 1983.

5. Herman GE, Greenberg F, and Ledbetter DH: Multiple congenital anomaly/mental retardation (MCA/MR) syndrome with Goldenhar complex due to a terminal del(22q). Am J Med Gen 29: 909-915, 1988.

6. Benacerraf BR, and Frigoletto FD Jr: Prenatal ultrasonographic recognition of Goldenhar's syndrome. Am J 
Obstet Gynecol 159: 950-952, 1988

7. Feingold $\mathrm{M}$, and Baum J: Goldenhar's syndrome. Am J Dis Child 132: 136-138, 1978.

8. Jones KL (Ed): Smith's Recognizable Patterns of Human Malformations, 4th ed. Philadelphia, WB Saunders Co, 1988, pp 497-500.

9. Kennedy LA, and Persaud TV: Pathogenesis of developmental defects induced in the rat by amniotic sac puncture. Acta Anat 97: 23-35, 1977.

10. Rollnick BR, Kaye $\mathrm{Cl}$, Nagatoshi $\mathrm{K}$, and Martin AO Oculoauriculovertebral dysplasia and variants: phenotypic characteristics of 294 patients. Am J Med Genet 26: 361-375, 1987.

11. Potter EL: Facial characteristics of infants with bilateral renal agenesis. Am J Obstet Gynecol 51: 885-888, 1946.

12. Hilson D: Malformation of ears as a sign of malformation of genitourinary tract. Br Med J 2: 785-789, 1957.
13. Heimler A, and Lieber E: Brachio-oto-renal syndrome: reduced penetrance and variable expressivity in four generations of a large kindred. Am J Med Genet 25: 15-27, 1986.

14. Walpole IR, and Hockey A: Syndrome of imperforate anus, abnormalities of hands and feet, satyr ears, and sensorineural deafness. J Pediatr 100: 250-252, 1982.

15. Leung AK, and Robson WL: Association of preauricular sinuses and renal anomalies. Urology 40:259-261, 1992.

16. Zerin JM, Ritchey ML, and Chang AC: Incidental vesicoureteral reflux in neonates with antenatally detected hydronephrosis and other renal abnormalities. Radiology 187 : $157-160,1993$.

17. Argueso LR, Ritchey ML, Boyle ET Jr, Milliner DS, Bergstralh EJ, and Kramer SA: Prognosis of patients with unilateral renal agenesis. Pediatr Nephrol 6: 412-416, 1992. 